\title{
Horticultural therapy as a tool of healing persons with disability on an example of Support Centre in Kownaty
}

\author{
Marzena Suchocka, Ewa Kosiacka-Beck, Izabela Myszka, Anna Niewiarowska
}

Warsaw University of Life Sciences - SGGW, Nowoursynowska 166, 02-787 Warszawa, Poland, *e-mail: marzena.suchocka@interia.pl

Received: 10 October 2018 / Accepted: 8 April 2019

\begin{abstract}
Nowadays, the interest in nature's impact on our mental and physical health is getting more and more common worldwide. The nature is able to relax, gentles nerves, arouses positive emotions. Greenery is a basic and most valuable part of human lives, which accompanies people and also a priceless space both, near single-family houses and public spaces as well.

Scientific studies shows, that a contact with nature may approve social function, has an influence on our mood, physical health, mental condition, reduces stress and pressure. It gives us many benefits on mental, physical and intellectual ground. Horticultural therapy is a supportive element and such an effective method in healing many afflicions and rehabilitation proces.

In horticultural therapy it is possible to use tasteful values, which references to landscape's charm, greenery composition and single plants, their flavor, colours and textures. Beneficent impact of plants is connected to incentives, which influence on people and to the large variety of activities related to the plants care. In this type of horticultural therapy, we must take into account all aspects connected to design - personalised by exact needs of user, adjusted to dysfunctions and possibilities of people, who takes a use of therapy in garden.

The present studies shows that guidelines to therapeutic garden design must result from many spatial and greenery analysises, assessment of posssibilities and limits of the place, the way of its actual use and strict cooperation between the gardener and therapist. We assumed that designer should participate very actively in the therapy of potential users in order to know the specification of desease.
\end{abstract}

Key words: garden, therapy, disability, disorders, greenery design, therapeutic centers.

\section{Introduction}

The definition of health by WHO (World Health Organization) depicts health as a state of abslute, physical, mental and social well-being. The significant impact on health especially mental health, has the style of work, leisure and a way of spending your freetime (Płotka, 2003; Latkowska, 2013). Undoubtedly, each garden near the centre, should potentially be able to improve the quality of life and helps to keep users healthy, specially that it has been proved that hortiterapy may be an effective treatment for mental and behavioral disorders such as schizophrenia, dementia, depression, and terminal-care for cancer (Kyung \& Sin, 2018;
Kamioka et al., 2014). However, garden space should be designed in a specific and proffesional way. The assessment of therapy's difficulty is needed and all attributes of the garden should be pertinent to users' specification (Smrokowska-Reichmann, 2006a, 2006b). The process of space design should be basen on the rules standing for landscape architecture. In the case of horticultural garden the knowledge should be extended to the needs of therapists, who take care of given garden users groups (KalinaGagnelid et al., 2016).

Horticultural therapy is a method which extends traditional ways of therapy. Designers applie it in order to create a space in which gardening activities are used to 
achieve some specific therapeutic or remedial goals. It focuses on improving social, physical, mental and cognitive functioning of users and also on their mood (Latkowska, 2008). Gardens and programmes designed in applicable manner may develop a vide variety of benefits like: increasing the feeling of autonomy, they strenghten social interactions, stimulating proces of creative expression, allowing for reinstating the positive view about themselves and their abilities and possibilities, it also has an impact on forming the bond between human and nature. Research on the effects of gardening on the condition of man (Soga et al., 2017) provided solid evidence of the positive effects of gardening for health. According to the authors, a regular dose of gardening can improve the health and social functioning of humans. Horticultural therapy is basen on many scientific discoveries from different fields, for example environmental psychology, medicine, landscape architecture (Stigsdotter \& Grahn, 2002). It is the field which keeps developing. More accurate studies about the greenery impact on human started being conducted with the end of 18 century. Dr Benjamin Rush, who was considered as the creator of american psychiatry, nowadays is also called „the father of horticultural garden”. He drew attention to the therapeutical impact of greenery activities. He advised gardening as the „cure” for anxiety states or depression and it also reacted against neglecting patients of themselves. Rush's perceptions started further studies on this field. In Europe, the creator of modern psychiatry - Phillipe Pinel, has changed not only the way of patients' treating, from forceless to caring, but also he considered work in the field as something that develops: quietening, relaxing and circulation smoothing (Smrokowska-Reichmann, 2006). Refl (1973) underlines, that horticultural therapy is not someting new and he evokes some of methods in Spain, where essential benefits of greenery activities were noticed in 1806. Dobroczynnie wpływały one przede wszystkim na pacjentów chorych psychicznie. How important is the garden in the treatment of disorders and stress was also studied by other authors (Adevi \& Mårtensson, 2013) taking active part in the rehabilitation in the Alnarp rehabilitation garden in southern Sweden. The article is based on which they consider crucial for their recovery.The Polish pioneer of horticultural therapy and also one the best knows was Apolinary Tarnawski [1851-1943], who was the victim of compounding living conditions in overpopulated cities. Thanks to that Tarnawski hammered his own method of horticultural out, which was implemented in Kosowo Huculskie beyond Kołomyja in Kresy Wschodnie (Karpaty, Czarnochora), where in 1891-1939 in historic palacepark complex created his own famous clinic - naturalistic health resort. The impact on ways of clinic functioning exerted Tarnawski's experiments in priest dr Kneipp's german clinic, who was one of pioneers of hydrotherapy water treatment basen on thermal shock method - putting the organism under the influence of alternately icy and hot water. Kneipp proclaimed the theory that human health is related to frequent communing with water - swimming, massages, water gymnastics. These theories interested Tarnawski and right after the convalescence he decided, after modification, to implement tchem to his methods. First and foremost, he was using femous methods of Lahmann and Kneipp, who were supporters of horticultural therapy, herbalism and rational way of nutrition, with paying such a strong attention to user's personality. Tarnawski heightened dietary rigours, emphasized the role of physical exercises and hardening off, creating his own system of natural medication (Nicieja, 2011).

In the first half of 20 century, many trailblazing programmes of horicultural gardens appeared and were dedicated to patients with mental diseases (mostly veterans of I world war, who were one of the most important gropus) (Taylor, 2008). Significant progres of horticultural therapy followed in Great Britain after II world war, then in ' 60 s and ' 70 s in USA. Horticultural therapy was implemented in many agricultural universities in USA in '70s (Nowak, 2008). The hortitherapy is impoving nowadays faster and faster. New therapeutic programmes and conceptions are being created, exchange of experience is followed, professional literature gets expanded and in many educational centers more and more specialists obtain needed education. Currently, AHTA (American Horticultural Therapy Association), which cooperates with ASLA (American Society of Landscape Architecture) contributes to the popularization of hortitherapy in USA. In Canada it is CHTA (Canadian Horticultural Therapy Association) and in Great Britain The Thrieve, which catchphrase sounds ,using garden to change lives", they highlight that organization's operation is connected to both, greenery and human. In New York's university the world-renowned station functions, it works on hirticultural gardens in scientific way - it is the Rusk Institute of rehabilitation Medicine (Smrokowska-Reichmann, 2006a).

World ,horticultural”, which is usually replaced by the world garden therapy, derives from fusing two worlds latin „hortus” and greek ,the-rapeuein”, which means „to treat, to glorify" (Szewczyk-Taranek \& Tomaka-Tomasik, 2013). According to definitions „Garden therapy” is professionaly conducted, focusen on the user method of therapy, in which garden activities are used in order to achieve specific therapeutic or rehabilitative aims. Therapy concentrates on the maximization of social, cognitive, mental, physical functioning and general health support and positive mood (Haller \& Kramer, 2006). Garden is unique in terms of the fact, that it is able to activate all senses: sight, hearing, smell, touch. It creates its own space, havin its floor, walls and ceiling but in unlike architecture it can offer not only three-dimensial space experiences but also the forth dimension - time. Aside from arousing perception, 
physical activity is also important becouse of its abilities to letting patients making use of the therapeutical potential of space. It is essential to find the balance between ,being in garden" and performing activities in it. It is necessary to match forms of activities to specific group of users, taking into consideration their abilities, motor possibilities and possible contraindications of some activities (Stigsdotter \& Grahn, 2002).

In this situation garden should offer flexible scheme and space, it is worth to draw attention to the existance of ,,indoor-gardening” in mind of patients, who are not able to make use of traditional form of garden, for example patients of long-term care. In these spaces special emplacements are installed, which allows these patients for attempting independant greenery activities (i.e. disabled person, who moves thanks to wheelchair, needs specific raising elevations, thanks to which they have direct access to plants). „Indoor-gardening” comprises implementing to spaces plant boxes and cut flowers. The significant advantage of ,indoor-gardening" is its possibility to conduct activities during winter or unfavorable weather conditions. One of the most common example of horticultural therapy is glasshouse, but also winter gardens, palm house or orangery. It could be buutterfly conservatory as well. That kind of places serve as a place of abutment, where aside from plants impact, incentives are being controlled by space's temperatur, radiation and movement and humidity of air (Boniek-Poprawa, 2011; Araźny \& Smukała, 2011). Modern technologies allows for creating objects, which have their own climate cinditions, for example the usage of lamps which emite light similar to the natural one. They are able to overcome the lack of light and limit sleep disorders and depressive state as well, which may be coused by light circuit disorder (Kolek, 2006). First glasshouse, which was created from therapeutic reasons, was build in 1879 year nearby psychiatric hospital in Philadelphia (Smrokowska- Reichmann, 2013). Green walls has huge therapeutic potential, their plant material and conducted processes may have an impact on residents' moods, becouse of their ability of saturating air with oxygen and keeping right level of humidity but they may also has an influence on particular disorders (Greenroofs, 2019).

According to foregoing studies, there must be four conditions fulfilled to call activities in garden horticultural recreation (Fig.1). These conditions are: the patient with diagnosed disorder - illness - disability, determined therapy's aims matched to patient's needs and ability. The therapist is also necessary - it is a person, who is qualified and authorised to conduct the therapy. The last conditio is procedurę of therapy proceeding, which main tools are plants (Szewczyk-Taranek \& Tomaka-Tomasik, 2013).

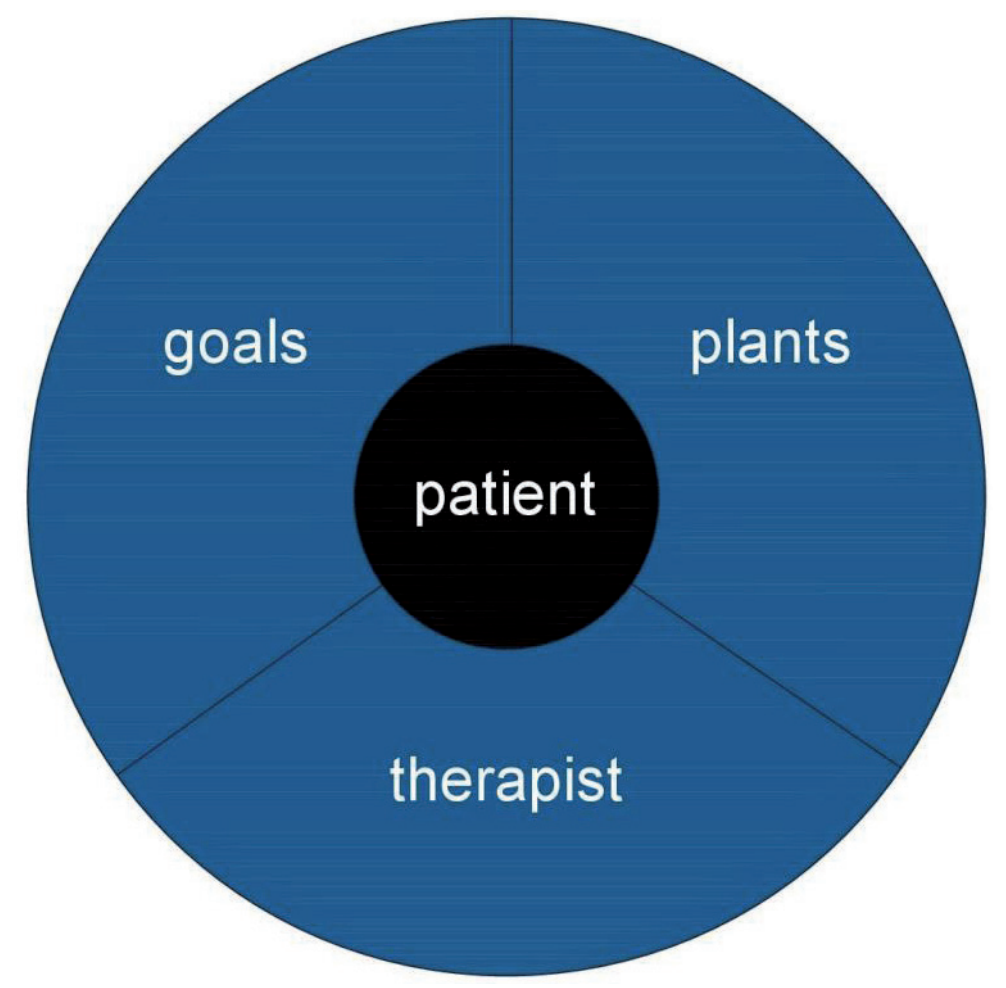

Figure 1. Diagram showing the necessary cooperation at the level of patient-goals-plant-therapist (on the basis: Szewczyk-Taranek \& Tomaka-Tomasik, 2013, www.dps.pl, accessed 1.01.2015) 
However, adjusting the program to illness's character is the most important factor in horticultural gardens design. Knowing every programing contingency and using legitimate solutions depends not only on designers vision but also on coopoeration with therapist is crucial. The size of solutions, which determines individuating program is the essential element, which allows for designing spaces adjusted to each disorder. Sometimes it is necessary to use extremely different spatial solutions (Kalina-Gagnelid et al., 2016).

It is difficult to restrict hortitherapy to having impact of greenery on human. Becouse of its conducting changes and wide variety of forms, garden has a huge indluence on perception. In the light of terapy by nature treatment, many methods and techniques can be used in garden, for example: zoototherapy, therapy through the play, kinesis therapy, terrain therapy, heliotherapy, dendrotherapy, aromatherapy, etc. Prof. Konarska from Pedagogical University in Cracow in the article written on the occasion of conference „Hortiterapia 2012”, writes that horticultral garden is a mix of art therapy elements, becouse of the reason that patient spends time in the surrounding of greenery, what delievers some estetic experience; ergotherapy - through activities in garden, but also greenery nursing and psychotherapy direct stimulating of emotional, decision-making and cognitive processes during passive and active commune with plants. This is the kind of therapy, which is accurate for every disorder or disability. Each charge can benefit from this therapy, all the more there are many different forms of horticultural therapy, starting form people with disability to those completely mere. Konarska (2012) adds, that „Even if your body is completely numb, psychological activity may be roused and stimulated in proper chosen plants surrounding, and this - even though it does not translate to physical development - certainly improves the quality of life, which can not be neglected in modern medicine and psychology". Hortitherapy supports therapy for those, who have mental disorders or are physically disabled and is practised in nursing home for seniors (considering seniors with dementia), and furthermore it may be a filler for working on addiction, or be a favor for social activation and resocialization (Smrokowska-Reichmann, 2006).

Horticultural garden is an innovative method in our country, but the interest around it is growing constantly. Aside from that, hortitherapy is not acclaimed method of therapy or vindication in medical surrounding; implementing hortitherapy or its elements is intuitive in many centres (Szewczyk-Taranek \& Tomaka-Tomasik, 2013). Many schemes came into existance within the limits of this therapy. The project called „Ogród Zdrowia” is functioning in Cracow and is carried out by Wojewódzki Szpital Pediatryczny im. św. Ludwika in Cracow (Botanical Garden of Jagiellonian University and Agricultural University of Cracow). The garden is destined to children with celebral pal- sy. The pilotage project of hortitherapy was conducted and assumed to support the rehabilitation process of children physically disabled. There were children in the age from 7 to 16 , mostly with neurological disorders. They were busy with plants observation, greenery nursing and sensotial recognising. The director of Wojewódzki Szpital Dziecięcy w Krakowie - Stanisław Stępniewski - made a judgement: „I would never expect, even though I am a doctor with such a huge experience, that this kind of complementary therapy would be so helpful in conventional therapies" (Hortiterapia. Terapia ogrodnicza pomaga..., 2018). The winter garden for patients of Zakład Pielęgnacyjno-Opiekuńczy im. ks. J. Popiełuszki exists also in Toruń. Some time ago from Swiss fund the project of horticultural garden on the area of Nursing Home Care in the village called Ruskie Piaski near Zamość was financed. Subjects connected to hortitherapy were addet at the Agricultural University of Cracow and from new 2010/2011 academic year within the limits of course, the new subject „Modern trends in gardening: therapy with decorative plants" was implemented. It involves matters connected to design and conducting therapeutical classes, and also designing therapeutical gardens (Szewczyk-Taranek \& Tomaka-Tomasik, 2013). In Warsaw University of Life Sciences in 2014/2015 academic year, the subject called ,The project of horticultural garden" was implemented. It is a faculty for engineery students, which extends students' knowledge and abilities to extra-curricular aspects. The emphasis is laid to coordination with therapeutical centre, designing spaces in line with accepted idea. On the University of Warmia and Mazury in Olsztyn graduate studies in hortitherapy are conducted (Płoszaj-Witkowka et al., 2014).

\section{Study area}

Inquiry of subject literature shows, that studies confirm unquestionable beneficial impact of nature to human, which creates the solid basic justifying the horticultural garden effeciveness. In this situation it is legitimate to create some guidelines for garden development projects, which may be enable for leading therapeutic classes and support the therapy of common disorders.

The Centre of Support in Kownaty was encompassed by the project. The study area is located in the eastern part of the Podlasie Voivodeship, in the Łomża District, Piątnica commune, located about $14 \mathrm{~km}$ north-east of the Łomża city. It is relatively young agency. In 2000 old building which used to be school, with one hectare parcel in Kownaty was commited to the Polish Committee of Social Support by the village mayor and the Administration of Piątnica Borough and it was destined to be a Nursery House. After many changes in 2009 the Centre of Support in Kownaty was opened up. The centre's territory is 
divided to functional areas: recreational, economic, usable and communicational. There is an extensive lawn, fruit trees, a tiny arbour and biological sewage works in recreational area. Periodically, a huge garden tent is unfolded up there. Arbour is used mostly as a space of spending free time, meetings and integration. During summer, the net for games is unfolded, which allows for many other forms of active rest of patients. The space of recreational area is used for picnics organization, obiously for patients and their families, friends or centre's guests. One part of this area functions as the space of greenery nursing use vegetables are being cultivated here. In this area we can find a folic tunel and a little glasshouse used for tomatoes cultivating. There is salso a compost bin on the west side of area but it is out of use for this moment. On the north side green-legged hens are on the run and a little cote is located but it is in use only during summer time. The utiity area is made of buildings, which are used for preserving tools and garden equipment, which is necessary to take care of garden and animals living in it. In this area we can also find: a dumpster, a cote and a tiny rabbit warren, where some rabbits are reared up by patients. In the main building tasks of the Support Centre are being realised, the building is equipped with elevator for physically disabled users. The communicational area was divided by a walkway and shared zone and also for desired paths.

\section{Material and methods}

The starting point of a work on horticultural projects were theories and studies conducted in order to get to know specificity of disorders and disabilities taking into consideration the possibility of using estetic and appropiable values of garden. In the limits of pilotage studies the query of source materias was conducted, it concerns different aspects of garden therapies and studies of approximate character centers, which supports people with different disabilities and disorders, where are temporary and momentary patients. These are places, which assumes integration, mutual help and adjusting therapy to individual needs of patients.

The project elaboration and realisation of garden projects were put under preliminary studies and they accompanied to spaces near domestic and foreign centres. The online query allows for projects overview and ther analysis, which includes creating assumptions tofunctional scheme of garden. It is necessary to concellate to invidualize the project again and take into account the necessity of building ,elastic" programmatic frames in this place. The knowledge of disabilities specification and patients needs is the starting point to implement changes in conception grounded by designer's knowledge. That is how the algorithm of design proceeding (Fig. 2) is modified by the stage of consultation including therapy.
The first stage of work was familiarizing with daily rhythm and activities of centres and collecting all informations of individual users, the accurate diagnosis of limits and possibilities of their functioning, resulted from their disorders. The next essential stage was the consultation and conversation with therapists, observation and active participation in daily functioning and life of centres dwellers (patients, families and employees). On this basis the programme of garden users activity was created. Simultaneously the profile of object was done, it included data about its location, surrounding but also planning and nature conditions. Gathered informations were also used to make analisys of terrain: domesticating around centre a tan angle of existing infrastructure and its usefulness, insolation, safety, identyfication of different ardousnesses and assessment of the possibility to create horticultural garden, adjusted to specified group of users.

On the basis of field works and informations obtained with users, the scheme of functionaly-spatial areas for garden and guidelines to its development was created. The result of analytical proces was conception of space development with therapeutic function, which would allow for horticultural activities like plants cultivation and greenery nursing but also passive form of spending free time, which could result in getting rid of stress and equalizing the state of mind.

Methodology of designed horticultural garden included indivisualization of this process.

\section{Results and discussion}

As a result of gathered informations, conducted analysises and consultations with centre's employees, design guidelines were determined. They allowed for designing space adjusted to posssibilities and needs of groups' users. Areas, in which it is possible to lead classes from garden activities were assigned, as so were areas providing the possibility of fading out and relaxing, which fits in trends used in hortitherapy, both active or passive. Sempik at al. (2003) writes, that „Garden therapy is nothing else like using plants by professional as a centre to achieve some clinically definied aims" and adds that ,social and therapeutical gardening is a process which allows an individual for achieving great state of mind thanks to the use of plants and work in the grden. This effect might be achieved by active and passive participation" (Sempik et al., 2003). Anna Bach explains, that hortiterapy can be divided into passive and active. Passive is a living and being surrounded by nature, while active is based on work and physical contact with greenery. This is primarily about motivating nature to work in the garden. It is pleasant and motivates to a greater than usual effort. Szewczyk-Taranek and Tomaka-Tomasik (2013) writes, that the surrounding of garden for those, who are 


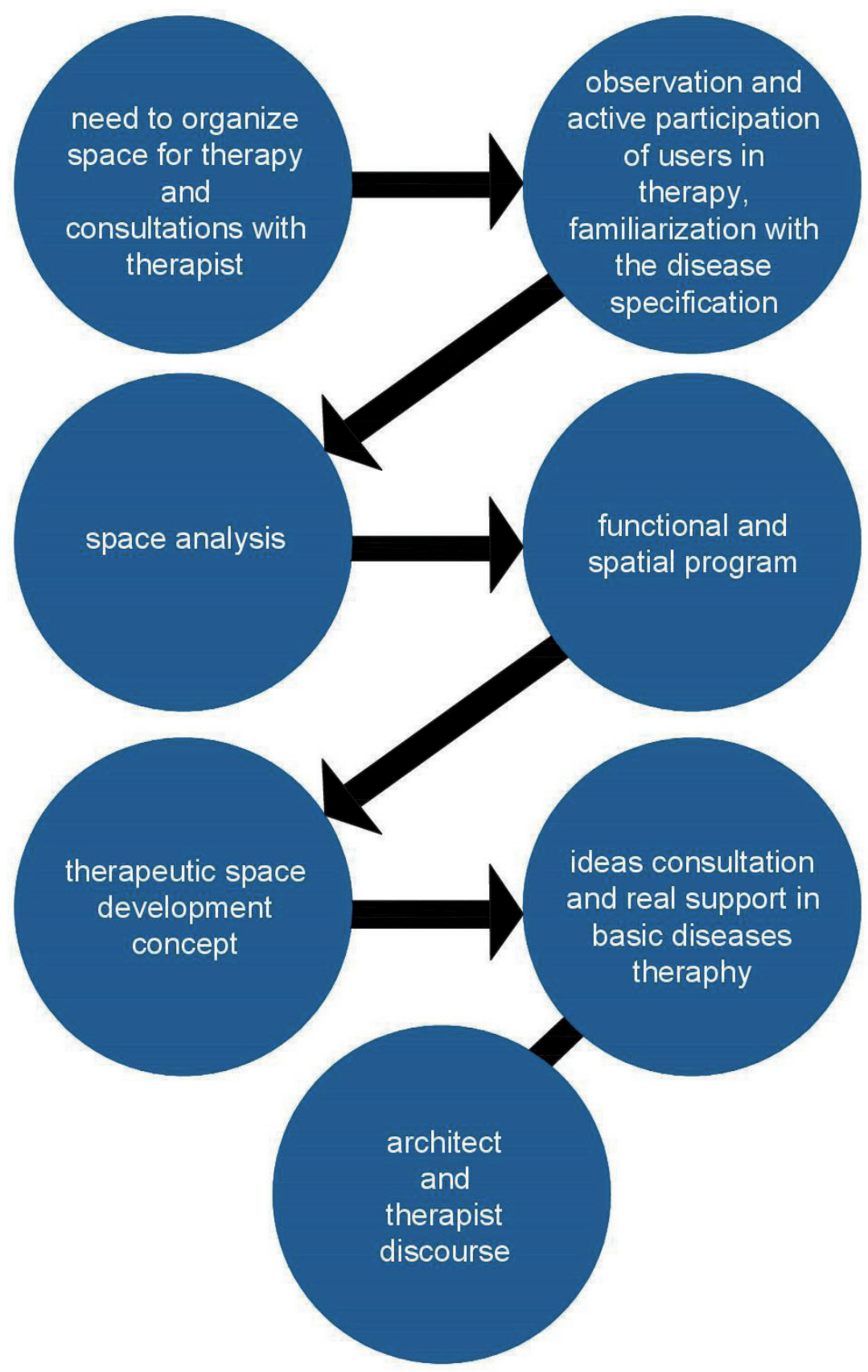

Figure 2. Workflow in the proces of therapeutic garden designing

being treated, is on the one hand a relaxing factor, but on the other hand it motivates them to physical activity and initiative in taking action and work up.

The garden space is attractive during year seasons. Shown conception includes elements, which stimulate senses: vision, hearing, smell, flavour, touch. The composition of communication was designed in the way, which takes into consideration users, who are physically disabled. Width and kind of paths were adjusted, communication barriers were removed. In order to increase the sense of privacy, it was suggested in the project to create spaces more public (open) and some quiet (intimate). The conception of interiors included the element of pursuing floor, building a roof (in order to overshadow places, which are very sunny) and walls. Walls are built with greenery, which is treated as the essential element. It is such an important attribute for all users but also important in particular for those, who are mentally disabled. This aspect is built 
especially with natural elements, diversity of their forms, textures, colors, flavours and noises. Greenery is salso the element, which - through work - provides to patients the sense of efficiency and allows therapists for leading horticultural classes. The additional asset is culinary use of hervest. British studies conducted among past psychiatric patients shows, that $20 \%$ of interviewers found permanent employment in aboriginal labor market, further $25 \%$ works sporadically or seasonally in gardening. In the group of responders it was alleged that $68 \%$ reduced their stay in psychiatric centre, what allowed to save more than 4 million euro on treatment costs (Sempik et al., 2003).

Designing assumptions and garden elements designing have an impact on horticultural function of garden. The collation depicting relations of assumptions and expected results is shown in tabular collation (Table1).

Table 1. Relation between programming assumption and design aims for centre in Kownaty

\begin{tabular}{|c|c|c|}
\hline \multicolumn{2}{|r|}{ Design guidelines } & Individualistic designing aims \\
\hline \multirow{16}{*}{ 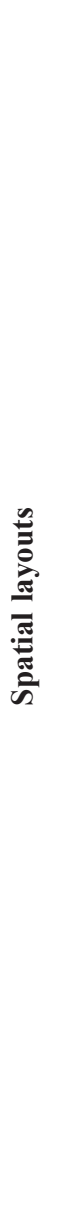 } & $\begin{array}{l}\text { dividing garden on areas taking into consideration active and } \\
\text { passive aspect of hortitherapy }\end{array}$ & adjust to users' needs realization \\
\hline & legit space composition & sense of safety and space awareness \\
\hline & path tieing the whole garden & discovering new territories, safe return \\
\hline & $\begin{array}{l}\text { distincting space for plant cultivation, arranging spaces for } \\
\text { chests used for cultivation }\end{array}$ & $\begin{array}{l}\text { the possibility of takin on work by physically disabled } \\
\text { users }\end{array}$ \\
\hline & glasshouses adjusted to use by disabled person & $\begin{array}{l}\text { therapeutical impact of microclimatic and all-season } \\
\text { work }\end{array}$ \\
\hline & spaces for leading ergotherapy classes and other therapies & the possibility of taking on job, activation, socialize \\
\hline & distincting some space for an orchard & greenery activities \\
\hline & implementing spaces for resting, relaxing & mobilization \\
\hline & $\begin{array}{l}\text { creating places more and less cozy, in the limits of possibilities } \\
\text { of users' privacy control }\end{array}$ & isolation possibilities, sense of safety \\
\hline & $\begin{array}{l}\text { districting some enshadowed places and arrangement of sunny } \\
\text { areas }\end{array}$ & adjust to users' needs realization \\
\hline & plates with plant species names & implementing cognitive aspects \\
\hline & $\begin{array}{l}\text { elements easing the orientation to patients, compositions } \\
\text { rhythm and repeatability }\end{array}$ & sense of safety \\
\hline & equipped with water element & mobilization of senses \\
\hline & $\begin{array}{l}\text { elimination of visually unattractive elements like trash bins, } \\
\text { designing wooden carport embosoming space }\end{array}$ & \multirow[t]{3}{*}{ space adjust to users' needs realization } \\
\hline & artificial lightning in main garden & \\
\hline & placing bins on garden's territory & \\
\hline \multirow{4}{*}{ : } & $\begin{array}{l}\text { designing greenery which is basically easy in nursing and } \\
\text { maintaining, plant species which are decorative, have medical } \\
\text { use, implementing lawn surfaces }\end{array}$ & $\begin{array}{l}\text { senses mobilization, implementing cognitive aspects, } \\
\text { possibility of taking on work by physically disabled } \\
\text { users }\end{array}$ \\
\hline & avoiding poisoning and prickly greenery & safety \\
\hline & $\begin{array}{l}\text { designing greenery, both low and high, which creates garden's } \\
\text { interiors }\end{array}$ & \multirow[t]{2}{*}{ isolation possibilities, sense of safety } \\
\hline & $\begin{array}{l}\text { preserving trees in designed space, fulfilling gaps in tree } \\
\text { lanes, closing garden's visual connections with outdoor space, } \\
\text { limiting patients peeking }\end{array}$ & \\
\hline
\end{tabular}


Guidelines are the designer's answers on needs, which results from the specification of disability and the fact that in hortitherapy spatial and greenery aspects are being taken into consideration. Guidelines became the basic for creating a concept of arranging terrain, which gives the opportunity to lead horticultural classes in active form through greenery nursing and activities and also passive form of spending free time, which couses the equalization of mind. This concept is shown in graphic in Figure 3.

The study center in case of garden in Kownaty with studies of centres with approximate character, allowed for elaborating the programme thresholds (Table 2) for horticultural garden, which supports proces of study revealing and mental disorders.

Studies demonstrates that the essential epart of mentally ill patients is work and engagement. It is also crucial to build the sense of safety, intimacy, realisation of isolation need pulling back the treatment on right time. The starting point for designing horticultural garden for those people is building spaces, which provides intimacy, arranging functional programme in the way, which gives the videst variety of possibilities connected with work in garden (what has an impact on body's mobility), sense of safety and activation of senses. Hortitherapy means not only plants but also space and activity, it is programmed for specific disability and results from therapeutical needs, possibilities and spatial conditions. It is not right to subordinate garden therapy only to plants and their impact on senses. Undoubtedly, plants perception has an impact on human senses, but much vider is the variety of therapeutical possibilities and interaction with landscape and nature. Designing space used in hortitherapy, the designer should represent both approaches: individual and holistic.

The scheme, in which relations between, patient, therapist and greenery is shown (Fig. 4) is not complete and requires to be filled in, becouse it does not include aspects connected to spatial and cultural values. Thus, thanks to conducted studies, the scheme of relations in proces of designing for hortitherapy should include the character of space. The spectrum of therapy in garden is way of wider than sensual feeling of plants and should not be limited to only these aspects.

\section{Conclusion}

Conducted studies shown that regardless of limitation, supporting the basic treatment of disorders by garden therapy

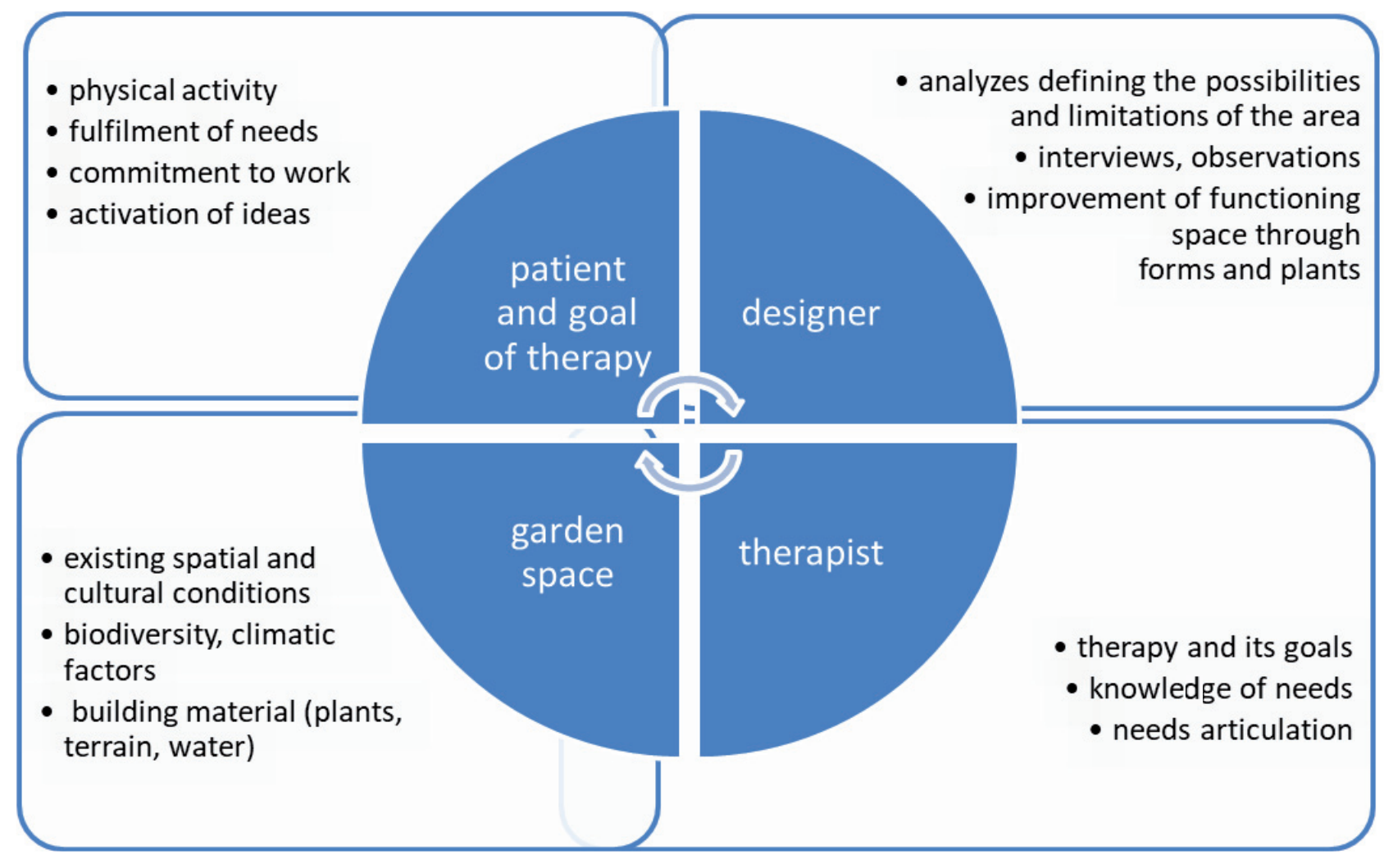

Figure 3. Diagram of relations in the process of designing a hortitherapeutic garden that supports the process of treating stress and mental disorders 
Table 2. Frameworks of horticultural garden, which supports the process of stress revealing and psychological disorders treatment

\begin{tabular}{|c|c|c|c|}
\hline Therapeutic value & Therapy's aims & Designers tasks & Designed element \\
\hline \multirow[t]{6}{*}{ Therapy up to work } & involvement in work & functionally-spatial areas & $\begin{array}{l}\text { decorative and useful flower } \\
\text { beds }\end{array}$ \\
\hline & $\begin{array}{l}\text { sense of efficiency and } \\
\text { autonomy }\end{array}$ & $\begin{array}{l}\text { assurance of places and choice of } \\
\text { elements, providing for physical } \\
\text { disability }\end{array}$ & greenery planting \\
\hline & $\begin{array}{l}\text { responsibility, } \\
\text { systematicity }\end{array}$ & places of appointment & animals feeding and nursing \\
\hline & $\begin{array}{l}\text { stimulation of creative } \\
\text { expression process }\end{array}$ & creativity of centre's patients & $\begin{array}{l}\text { gym, fields, exterior stages, } \\
\text { exterior cinema }\end{array}$ \\
\hline & interpersonal relations & $\begin{array}{l}\text { integration od group, hierarchy in } \\
\text { group }\end{array}$ & work organization \\
\hline & $\begin{array}{l}\text { restoring the positive } \\
\text { perceive of oneself and } \\
\text { ones possibilities and } \\
\text { abilities }\end{array}$ & $\begin{array}{l}\text { forming appropriate relations between } \\
\text { human and surrounding }\end{array}$ & $\begin{array}{l}\text { elements of domesticating } \\
\text { demanding cooperation }\end{array}$ \\
\hline \multirow[t]{2}{*}{ Sense of safety } & visual isolation, intimacy & $\begin{array}{l}\text { creating garden interiors and visual } \\
\text { barriers, backrooming }\end{array}$ & $\begin{array}{l}\text { fence, hedges and tree lanes, } \\
\text { walls within garden interiors }\end{array}$ \\
\hline & orientation in area & legible composition, signing places & $\begin{array}{l}\text { fence, additional elements, } \\
\text { signs, plates, path around whole } \\
\text { establishment }\end{array}$ \\
\hline \multirow[t]{2}{*}{ Senses mobilization } & excitation & \multirow{2}{*}{$\begin{array}{l}\text { project including: color, texture, ability } \\
\text { of obtaining noises, movement }\end{array}$} & \multirow{2}{*}{$\begin{array}{l}\text { decorative and useful flower } \\
\text { beds, lawn surfaces, gravel } \\
\text { paths, rocks }\end{array}$} \\
\hline & calmness & & \\
\hline \multirow[t]{2}{*}{ Motor activity of body } & physical activity & $\begin{array}{l}\text { project of communication and } \\
\text { system of garden's interiors, choice } \\
\text { of elements providing for physical } \\
\text { disability }\end{array}$ & $\begin{array}{l}\text { paths, useful flower beds, } \\
\text { elements for physical activities }\end{array}$ \\
\hline & relaxation & recreational forest glade & $\begin{array}{l}\text { tools for morning exercises } \\
\text { outside }\end{array}$ \\
\hline
\end{tabular}

seems to be essential. In fact, benefits may occur on different levels: physical, psychological, social, emotional and psychological development. On the intellectual plane it is acquiring new abilities like plants recognizing, garden nursery, improving communicational skills, arousing curiosity, developing the ability of world observing. In the limits of horticultural scheme's activity, the creaticity of users i salso aroused. Within social benefits, thanks to work in gardens users learn how to cooperate - collaborative aim and responsibility creates the bond between them; they learn to respect and esteem other opinions; they have the possibility of developing leader's features. The level of their integration is gworing. Work in garden learns to giving up on agressive behaviour in favour of socially ac- cepted behaviour. Increased self confidence and bigger trust between patients are some of many emotional benefits. Hortitherapy gives them also many practical benefits: they can organise different events in well-groomed garden, which motivates them to look after their own appearance and behaviour. Well-organised work in garden increases the will of engagement, self-confidence and may have a positive impact on improving some professional abilities, supporting the ability of employing disabled people. Hortitherapy is an effective method of supporting the rehabilitative proces. Scientific studies proves that connection between nature and human can lead to better social functioning, has na impact on mood, physical health, mental condition and reduction of stresses. 

A - garden lamp
B - container for compost
C - bench
D - stone
E - pergola
F - houses for birds
G - gravel path
$\mathrm{H}$ - reservoir
I- pavilion
$\mathrm{J}$ - shed
$\mathrm{K}$ - flower meadow
$\mathrm{L}$ - tables and chairs
$M$ - surface intended for growing herbs and vegetables

$\mathrm{N}$ - containers for growing herbs and vegetables

O - construction for creepers

P - greenhouses adapted to physically handicapped people

$R$ - greenhouse for soil cultivation

S - garbage container

$\mathrm{T}$ - TerraWay pavement

U - grassy vegetation

W - trash can

X - surfaces intended for active recreation

$Y$ - orchard

$\bullet \bullet \bullet \bullet \bullet \bullet \quad$ boundary

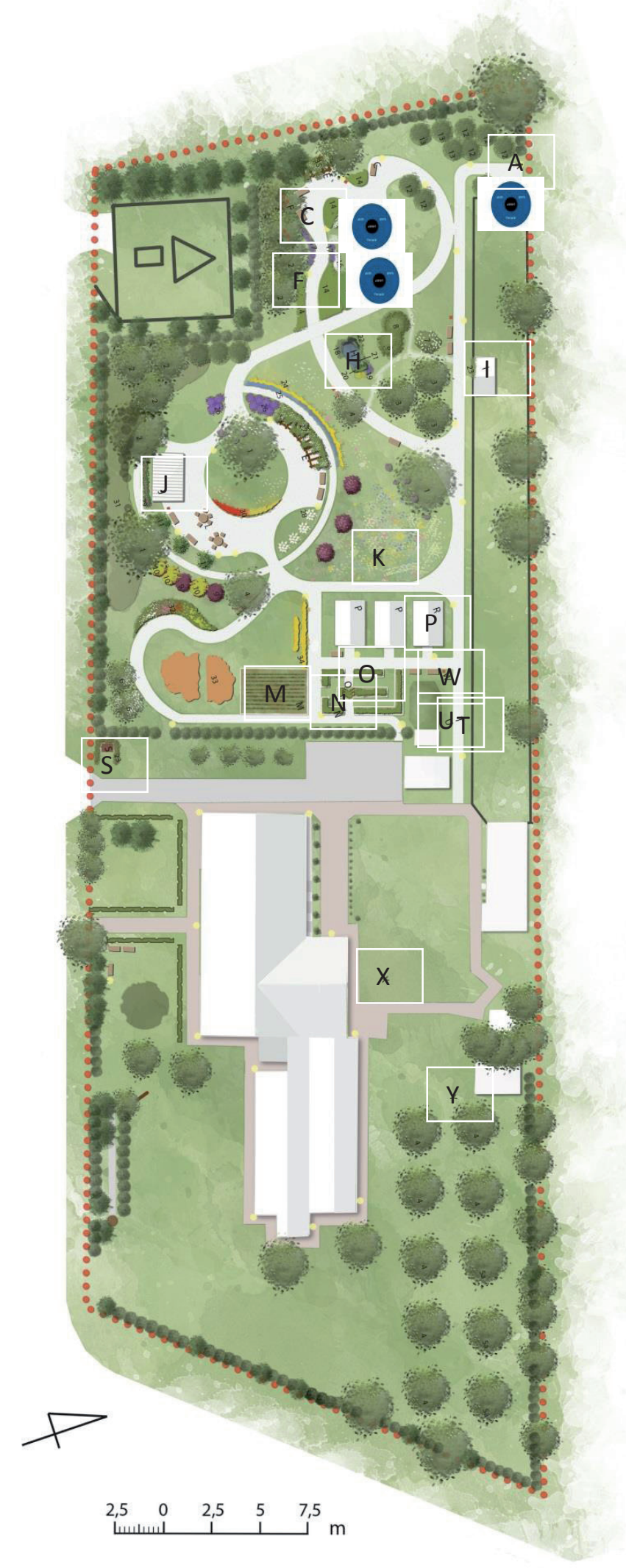

Figure 4. Conception of hortiterapeutical garden in Support Centre in Kownaty 


\section{References}

Adevi A.A. \& Mårtensson F. 2013. Stress rehabilitation through garden therapy: The garden as a place in the recovery from stress. Urban Forestry \& Urban Greening 12(2): 230-237.

Araźny A. \& Smukała K., 2011, Ocena bodźcowości warunków termiczno-wilgotnościowych w Polsce w przekroju południkowym w okresie 1976-2005 [Evaluation of the stimulating effects of temperature and humidity in Poland in a meridional cross-section in the years 1976-2005]. Annales UMCS Lublin-Polonia Sec. B, LXVI: 77-90.

Boniek- Poprawa D., 2011, Zmienność elementów pogody a nagłe przyjęcia do szpitala. praca doktorska, Uniwersytet Medyczny, Poznań. (http://www.wbc.poznan. pl/Content/232744/index.pdf), [Accessed 16.07.2015].

Haller R. \& Kramer L., 2006, Horticultural Therapy Methods. The Haworth Press, New York/London/Oxford .

Hortiterapia. Terapia ogrodnicza pomaga w leczeniu chorych dzieci, 2018, (https:/www.zielonyogrodek.pl/ terapia-ogrodnicza-pomaga-w-leczeniu-chorych-dzieci PAP - Nauka w Polsce), [Accessed 29.09. 2018].

Greenroofs, 2019, Indoor Living Walls. Psychological Therapy. Airborne Cleansing and My-Favorite Plants, LLC (http://www.greenroofs.com/content/Indoor-Living-Walls-Psychological-Therapy-Airborne-Cleansing-and-My-Favorite Plants.htm\#.W1Fo9NIzZnI), [Accessed 22.03.2019].

Kalina-Gagnelid A., Kosiacka-Beck E., Myszka-Stąpór I. \& Skibinska M., 2016, Ogrody hortiterapeutyczne dla osob doroslych z autyzmem - zasady projektowania [Horticultural therapy gardens for adults with autism guidelines for designing]. Annales UMCS, sectioEEE Horticultura XXVI (2): 13-25.

Kamioka H., Tsutani K., Yamada M., Park H., Okuizumi H., Honda T., Okada S., Park S.J. Kitayuguchi J., Abe T. Handa S., Mutoh Y., 2014, Effectiveness of horticultural therapy: a systematic review of randomized controlled trials. Compl. Ther. Med. 22: 930-943. (doi: 10.1016/j.ctim.2014.08.009).

Kolek Z., 2006, Oddziaływanie promieniowania optycznego na człowieka: korzystny wpływ i zagrożenia [The influence of optical radiation on human. Beneficial effects and health hazards]. Prace Instytutu Elektrotechniki 228: 269-281.

Konarska J., 2012, Terapeutyczna, psychologiczna i edukacyjna funkcja kontaktu $\mathrm{z}$ roślinami dzieci przewlekle chorych i niepełnosprawnych. Ogólnopolska Konferencja Hortiterapia - stan obecny i perspektywy rozwoju terapii ogrodniczych, Kraków. (http://www.hortiterapia.ur.krakow.pl/zasoby/57/hortiterapia_1_konferencja_2012.pdf), [Acceessed 28.11.2014].
Kyung H.K. \& Sin A.P., 2018, Horticultural therapy program for middle-aged women's depression, anxiety, and self-identify. Complementary Therapies in Medicine 39: 154-159. (https://doi.org/10.1016/j. ctim.2018.06.008).

Latkowska M.J., 2008, Hortiterapia-rehabilitacja i terapia przez pracę $\mathrm{w}$ ogrodzie [Hortitherapy - rehabilitation and therapy through work in the garden]. Zesz. Probl. Post. Nauk Roln. Wyd. SGGW, Warszawa 525: 229235.

Latkowska M.J., 2013, Hortiterapia-zdrowie z ogrodu. Panacea 4(45): 28-30.

Nicieja S., 2011, Głodzący lekarz z Kosowa, postać wyjątkowa. Głos Szczeciński, 2011.08.12, Szczecin: 8-9. (ISSN 0137-9178), [Acceessed 26.03.2019].

Nowak J., 2008, Terapia ogrodnicza $w$ krajach europejskich [Horticultural therapy in European countries]. Zesz. Probl. Post. Nauk Roln. Wyd. SGGW, Warszawa 525: 271-276.

Nowy projekt terapii chorych dzieci z wykorzystaniem roślin, 2011, (http://nauka.pap.pl/palio/html. run?_Instance $=$ cms_nauka.pap.p1\&_PageID $=7 \&$ dep $=276047 \&$ \&heckSum $=1947256258$ Serwis Naukowy PAP), [Accessed 29.09.2018].

Płoszaj-Witkowska B., 2014, Hortiterapia. Wydawnictwo Uniwersytetu Warmińsko-Mazurskiego, Olsztyn.

Płotka A., 2003, Zdrowy styl życia psychicznego. NeuroCentrum, Lublin.

Relf D., 1973, Horticulture: A therapeutic tool. Journal of Rehabilitation 39(1): 27-29. (http:/www.hkath.org/ Form/Scholar\%20Article/Diana\%20Relf/HORTICULTURE\%20-\%20A\%20THERAPEUTIC\%20TOOL. pdf), [Accessed 10.12.2014].

Sempik J., Aldridge J. \& Becker S., 2003, Social and therapeutic horticulture: Evidence and messages from reaserch. Thrieve and CCFR, Loughborough: Media Services Loughborough University. (https://dspace. lboro.ac.uk/dspace-jspui/bitstream/2134/2928/1/Evidence6.pdf), [Accessed 11.11.2014].

Smrokowska-Reichmann A., 2006a, Ogród jako miejsce terapii, część II, [in:] Wspólne tematy 07-08: 49-54. Dom wydawniczo - reklamowy „Tematy”, Kraków.

Smrokowska-Reichmann A., 2006b, Ogród jako miejsce terapii część III, [in:] Wspólne tematy 09, s.42-47. Dom wydawniczo - reklamowy „Tematy”, Kraków.

Smrokowska-Reichamnn A., 2013, Hortiterapia w teorii i praktyce, [in:]'Na temat"1/2013. Dom wydawniczo -Reklamowy „Tematy”, Kraków.

Soga M., Gaston K.J. \& Yamaura Y. 2017, Gardening is beneficial for health: A meta-analysis. Preventive Medicine Reports 5: 92-99. (doi.org/10.1016/j.pmedr.2016.11.007).

Stigsdotter U. \& Grahn P., 2002, What Makes a Garden a Healing Garden? Journal of Therapeutic Horticul- 
ture 13: 60-69. American Horticultural Therapy Association. (http://www.protac.dk/Files/Filer/What makes_a_garden_a_healing_garden_Stigsdotter_U Grahn_P.pdf), [Accessed 21.11.2014].

Szewczyk-Taranek B. \& Tomaka-Tomasik K., 2013, Hortiterapia w leczeniu osób objętych terapią długoterminową. (http://www.dps.pl/domy/index. php rob $=$ radar \&dzial=7\&art=1616), $\quad$ [Accessed 21.12.2014].

Taylor A., 2008, Horticulture in health: a brief history. (http://www.horticulturaltherapist.com/), [Accessed 23.11.2014]. 